\title{
Minimally Invasive Transcanal Removal of Attic Cholesteatoma
}

\author{
Ji-Eun Choi, Hee Jung Kim, Byung Kil Kim, and Il Joon Moon \\ Department of Otorhinolaryngology-Head \& Neck Surgery, Samsung Medical Center, Sungkyunkwan University School of Medicine, \\ Seoul, Korea
}

최소 침습 내시경 접근을 통한 상고실 진주종의 치료

최지은 · 김희정 · 김병길 · 문일준

성균관대학교 의과대학 삼성서울병원 이비인후과학교실

\author{
Received August 13, 2016 \\ Revised December 28, 2016 \\ Accepted January 3, 2017 \\ Address for correspondence \\ Il Joon Moon, MD, PhD \\ Department of Otorhinolaryngology- \\ Head \& Neck Surgery, \\ Samsung Medical Center, \\ Sungkyunkwan University \\ School of Medicine, \\ 81 Irwon-ro, Gangnam-gu, \\ Seoul 06351, Korea \\ Tel +82-2-3410-3578 \\ Fax +82-2-3410-3879 \\ E-mail iljoon.moon@gmail.com
}

Background and Objectives In treating attic cholesteatoma, traditional microscopic approach provides limited exposure to the attic space. Recently, the use of endoscope has emerged as a new treatment option for attic cholesteatoma. The aim of this study is to report the preliminary results of transcanal endoscopic removal of attic cholesteatoma and to evaluate the feasibility of endoscopic approach to attic cholesteatoma.

Subjects and Method Six patients with attic cholesteatoma were enrolled in this study from Sep 2014 to Oct 2015. Cholesteatoma was removed via transcanal endoscopic approach. We analyzed the clinical characteristics, surgical management and treatment outcomes.

Results All patients had attic cholesteatoma in the epitympanic space with scutum erosion. However, the disease was restricted to the epitympanic space in three patients, whereas a limited extension of cholesteatoma to the aditus ad antrum was observed in two patients, and mesotympanum was involved in the remaining one patient. All of the patients suffered from conductive or mixed hearing loss with mean air-bone gap of $17.4 \mathrm{~dB}$, and underwent endoscopic transcanal removal of cholesteatoma and scutoplasty. In three patients, the incus and malleus head were removed due to ossicular erosion, and a second-stage ossicular reconstruction was planned. No residual or recurrent diseases were noted during the follow-up period (mean: 13 months). No surgical complications were observed postoperatively, and favorable hearing outcome was obtained in all patients.

Conclusion Transcanal endoscopic approach was successfully performed in patients with limited attic cholesteatoma. Further studies involving a large number of patients with longterm follow-ups are necessary to prove the clinical efficacy of transcanal endoscopic approach in managing limited attic cholesteatoma.

Korean J Otorhinolaryngol-Head Neck Surg 2017;60(4):158-63

Key Words Attic cholesteatoma - Endoscope - Minimally invasive surgery · Transcanal endoscopic ear surgery.

\author{
서 론 \\ 중이강 내에 생기는 진주종은 상피조직의 과증식, 과분화 \\ This is an Open Access article distributed under the terms of the Creative Commons \\ Attribution Non-Commercial License (http://creativecommons.org/licenses/by-nc/4.0) \\ which permits unrestricted non-commercial use, distribution, and reproduction in any \\ medium, provided the original work is properly cited.
}

를 특징으로 하는 질환으로 선천성 진주종과 후천성 진주종
으로 나눌 수 있으며, 국내에서 시행된 국민건강영양조사에
서 중이 진주종은 $1.18 \%$ 에서 관찰될 정도로 비교적 흔한 질
환이다. ${ }^{1)}$ 후천성 일차성 진주종은 고막 내의 처음 발생한 위
치에 따라 상고실(epitympanum) 진주종과 중고실(mesotym-
panum) 진주종으로 분류한다. 이 중 상고실 진주종은 상고실 
함요(Prussack's space)에서 시작하여 상고실 후방, 상고실 전 방으로 진행되며 다양한 경로로 파급되어 유돌동구(aditus $\mathrm{ad}$ antrum)를 통하여 유양동으로 이르기도 하고 상고실함요 의 후하부로 내려가서 중고실의 후방에 도달하여 고실동, 안 면신경와(facial recess)를 침범하기도 한다. 후천성 진주종의 진행경로는 상고실 후방이 가장 흔하며, 다음으로 중고실 후 방, 상고실 전방의 순서로 흔하다. ${ }^{2,3}$ 내시경은 직선 시야를 가 지는 기존의 현미경과는 달리 더 넓은 시야를 가지고 있다는 장점이 있고 또한 다양한 각도의 내시경이 활용 가능하기 때 문에 중이강 내와 같이 사각 지역이 많은 부위에서 시야를 확보하면서 수술을 진행하기 편리하다. 내시경을 활용하여 이과 영역의 수술을 진행하고 좋은 결과를 보고한 여러 논 문 ${ }^{4-9)}$ 이 있으나 상고실 진주종에 대한 경외이도 내시경적 접 근법을 통한 치료 결과에 대한 연구 및 보고는 드물며 국내에 서는 보고된 바가 없다. ${ }^{10)}$ 따라서 본 연구는 국내에서 최초로 시도된 상고실 진주종의 경외이도 접근을 통한 내시경적 치 료 결과에 대한 임상적 고찰을 통하여 내시경을 이용한 최소 침습적 수술의 효용성 및 초기 치료 결과 등을 알아보고자 하고 향후 진주종 수술에서 내시경적 접근의 적용 영역 확대 를 위한 기초자료로 삼고자 한다.

\section{대상 및 방법}

본원에서 2014년 9월부터 2015년 10월까지 한 명의 술자에 의해 상고실 진주종으로 진단된 후에 내시경을 이용하여 경외 이도 접근을 통한 제거를 받은 6명의 환자 증례를 대상으로 의무기록, 방사선학적 검사 등을 후향적으로 조사하였으며
성별 및 나이, 이학적 소견, 청력검사 결과, 방사선학적 소견 (Fig. 1), 치료 결과, 수술 후 합병증 등을 분석하였다. 본 연구 에서 내시경을 이용하여 경외이도 접근을 통한 수술을 진행 하는 상고실 진주종 환자의 적응증은 측두골 전산화단층촬 영 결과를 토대로 진주종이 상고실 및 중고실에 국한되어 있 거나, 또는 상고실 진주종이 유돌동구 부위로 침범이 되어 있 더라도 유돌동 내 외반고리관이 이루는 반구까지는 미치지 못하는 주로 상고실 부위에 국한된 진주종으로 한정하였다. 또한 상고실 진주종이 유돌동 내로 침범한 것이 의심되는 경 우는 내시경적 접근법의 대상에서 제외하였다.

수술은 전신마취하에 진행하였으며 환자를 앙와위로 하고 머리를 반대측으로 돌린 후 경외이도 접근법을 통해 고막외 이도 피부판(tympanomeatal flap)을 거상하였다. 고실을 개 방하고 중이 및 상고실 부위의 병변을 관찰하고 병변을 제거 하였다. 진주종이 상고실의 전방 또는 상방으로 진행되어 있거 나 유양돌구 부위로 진행되어 있는 경우에는 골 소파기(bone curette) 또는 전동 드릴을 이용하여 골륜(bony annulus)이나 후상방 외이도 골벽 일부를 제거한 후 병변을 노출시켰으며 병변 제거 시 내시경을 이용한 미세수술에 적합하게 고안된 다 양한 도구들(Instrument Set for Endoscopic Ear Surgery, Karl Storz, Tuttlingen, Germany; Panetti Endoscopic Instrument Set, Spiggle \& Theis, Overath, Germany)을 활용하였 다. 모든 경우에서 0 도, 30 도 및 45도 내시경을 사용하였을 때 병변의 시야를 확보할 수 있었고 진주종낭의 끝을 확인한 상태에서 전술한 도구들을 이용하여 피막과 주변의 육아조 직들을 제거할 수 있었다. 진주종이 이소골 특히 침골과 추 골의 두부 부위에 단단히 부착되어 있고 침골과 추골의 미란
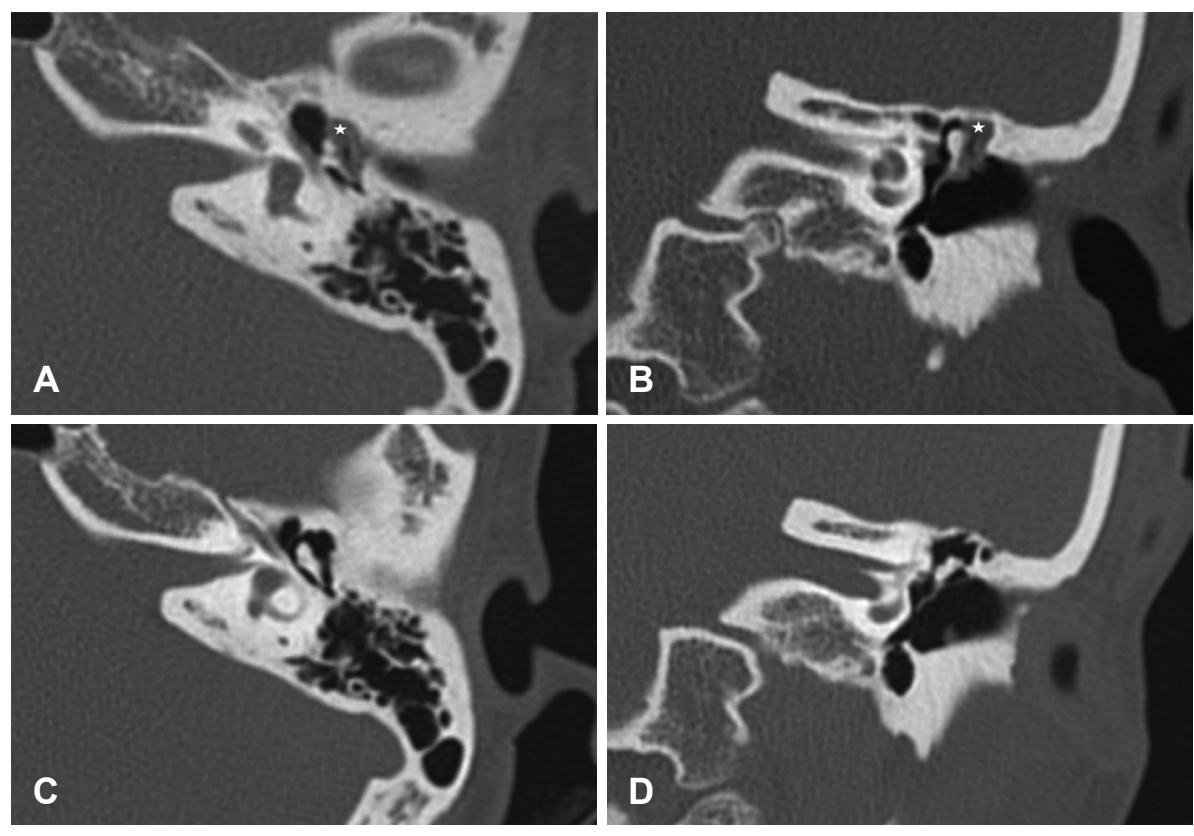

Fig. 1. Pre- and postoperative temporal bone computed tomography (CT) of case 1. Preoperative CT showed soft tissue density at epitympanic recess $\left(^{*}\right)$ (A and $B$ ). Postoperative CT which was performed 10 months after surgery showed clean middle ear cavity (C and D). 
이 의심되는 3 예에서는 침골-등골 관절을 분리한 후 침골을 제거하고 추골 두부를 자른 후 추골 두부도 제거하였다. 그 후 상고실과 유돌동구 부위의 잔존 병변을 30도 및 45도 내 시경을 이용하여 확인하였고 고막긴장건(tensor tympani tendon) 전방의 중고실과 상고실을 이어주는 공기통로를 확 보해주었다. 마지막으로 이주연골을 취득하여 상고실 및 후 윤상골 결손 부위를 연골을 이용하여 막아주고 연골막은 고 막 이식조직으로 사용하여 수술을 종료하였다(Fig. 2). 수술 시 사용한 내시경은 0 도, 30 도 및 45 도 $4 \mathrm{~mm}$ 또는 $3 \mathrm{~mm}$ 내시 경(Karl Storz)이었으며 광원은 LED nova 100(Karl Storz)을 사용하였다.

\section{결 과}

대상환자의 연령 분포는 23세에서 51세로 평균 연령 33.8
세였으며 남녀 성비는 같았다. 수술 전 시행한 이학적 검진에 서 상고실에 국한되어 고막이 함입된 경우가 3예, 상고실 부 위 외에도 함입이 동반된 경우가 3예 있었고 이 중 1 예의 경우 고막 천공이 동반되었다. 술 전 시행한 청력검사에서 기도골도 청력차는 7.5 30 dB까지 평균 $17.3 \mathrm{~dB}$ 이었다. 병변 범위 및 진행 정도를 파악하기 위하여 시행한 술 전 고해상도 측두골 전산화단층촬영에서는 상고실에 국한된 경우가 3예, 유돌동 구(aditus ad antrum)로 확장된 경우가 2예, 상고실에서 중고 실로 침범한 경우가 1 예였다. 이소골 미란이 방사선학적 검사 상에서 의심되는 경우가 3예에서 관찰되었다. 모든 예에서 전 신마취하에 수술을 시행하였으며 내시경하에 경외이도 접근 법을 통하여 상고실을 노출한 뒤 진주종을 제거하였고 수술 장 소견상 이소골 미란이 관찰되어 이소골에 진주종이 침범한 것이 의심되는 3 예의 경우에는 이소골(추골 두부 및 침골)을
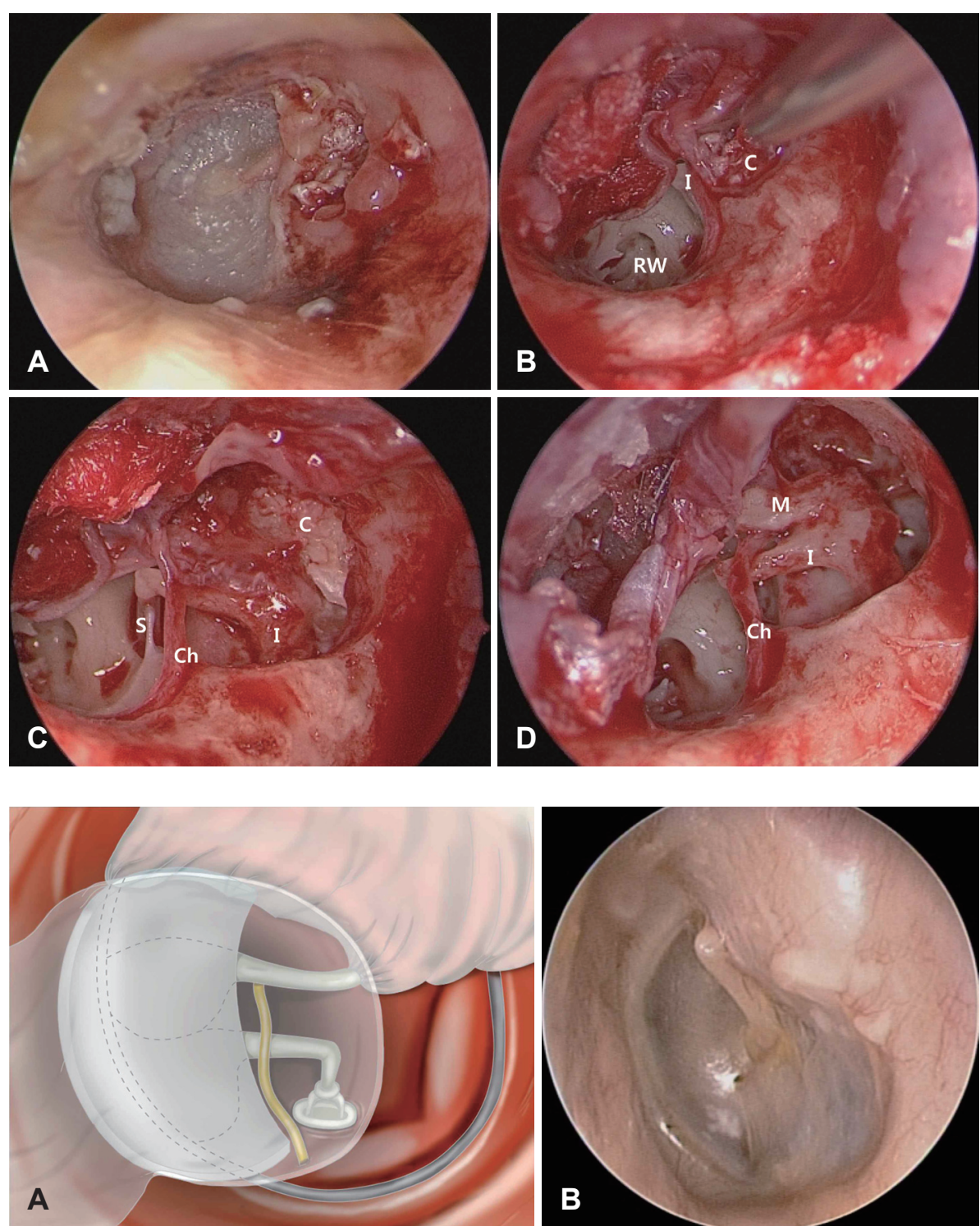

Fig. 3. Illustration of endoscopic attic reconstruction with composite cartilage graft. After endoscopic transcanal removal of cholesteatoma, scutoplasty was performed in our cases (A). Postoperative endoscopic finding after transcanal endoscopic attic cholesteatoma removal (B). 
수술 시 제거하고 이차 청력개선술을 계획하였다(Table 1). 진 주종이 유돌동구 입구부위로 확장된 2예에서는 상고실 및 후윤상골 부위를 조금 더 많이 제거해야만 진주종낭의 끝이 확인되었다. 상고실과 후윤상골 부위를 제거할 때에는 골 소 파기와 전동 드릴을 사용하였으며 특히 끝이 크게 휘어지고 흡인기가 끝에 달린 curved suction dissector 도구들이 진주 종낭을 골벽에서 박리할 때 매우 유용하게 사용되었다. 수술 후 진주종이 완전히 제거된 것을 0 도, 30 도, 45 도 내시경을 이용하여 확인 후 상고실 부위의 결손 부위를 연골을 이용하 여 재건하고(Fig. 3) 수술을 종료하였다. 수술 후 추적관찰 기 간은 평균 13 개월(최소 5 개월 최대 26 개월)이었다. 모든 환 자에서 마지막 추적관찰까지 고막 내시경 검진에서 잔존 진 주종 또는 재발의 소견은 관찰되지 않았으며, 이학적 검진에 서 발견되지 않을 수 있는 재발 여부 확인을 위해 수술 후 평 균 9개월경 측두골 전산화단층촬영을 시행한 4예에서 진주
종 재발 소견은 관찰되지 않았다. 진주종의 재발은 고막 내 시경 검진과 함께 술 후 9 12개월 사이에 측두골 전산화단 층촬영을 시행하여 평가하며 술 후 5년까지는 최소 6 개월 간 격으로 고막 내시경 검진을 시행하고 재발이 의심되는 경우 에는 측두골 전산화단층촬영을 다시 시행하게 된다. 술 후 3 개월째 시행한 순음청력검사 결과상 4분법(500, 1000, 2000, $4000 \mathrm{~Hz}$ )으로 계산한 평균 기도골도 청력차는 $9.8 \mathrm{~dB}, 6$ 개 월째 시행한 검사 결과는 $14.9 \mathrm{~dB}, 1$ 년째 평균 기도골도 청력 차는 $8.6 \mathrm{~dB}$ 로 수술 전 평균 $17.3 \mathrm{~dB}$ 과 비교하여 개선된 결 과를 보였다(Table 2). 특히 이소골 연쇄가 정상이었던 환자 중 수술 후 1 년째 청력검사가 가능했던 환자 두 명에서는 기 도골도 청력차가 $0 \mathrm{~dB}$ 과 $11.7 \mathrm{~dB}$ 로 좋은 결과를 보였다. 또 한 수술 중 이소골 미란이 확인되어 제거하고 이차 청력개선 술을 계획하였던 3예 중 2예에서 수술 후 기도골도 청력차가 $15 \mathrm{~dB}$ 이내로 호전되었고(환자 No 3 \& 4)(Table 2), 나머지 한

Table 1. Clinical characteristics of patients

\begin{tabular}{|c|c|c|c|c|c|c|c|c|}
\hline No. & $\begin{array}{l}\text { Age } \\
(y r)\end{array}$ & Sex & TM & Extent in imaging & Surgery & Operative findings & Tympanoplasty & $\begin{array}{l}\text { Reconstruction } \\
\text { graft }\end{array}$ \\
\hline 1 & 23 & $\mathrm{~F}$ & $\begin{array}{c}\text { Only attic } \\
\text { pocket }\end{array}$ & $\begin{array}{l}\text { Aditus ad } \\
\text { antrum }\end{array}$ & Primary & $\begin{array}{l}\text { Cholesteatoma in epitympanum, } \\
\text { extending to aditus ad antrum } \\
\text { Ossicular chain intact }\end{array}$ & $\mathrm{Tl}$ & $\begin{array}{l}\text { Tragal composite } \\
\text { graft }\end{array}$ \\
\hline 2 & 34 & $\mathrm{~F}$ & $\begin{array}{l}\text { Combined } \\
\text { retraction }\end{array}$ & $\begin{array}{l}\text { Limited to } \\
\text { attic }\end{array}$ & Primary & $\begin{array}{l}\text { Cholesteatoma in epitympanum } \\
\text { Ossicular chain intact }\end{array}$ & $\mathrm{Tl}$ & $\begin{array}{l}\text { Tragal composite } \\
\text { graft }\end{array}$ \\
\hline 3 & 33 & $\mathrm{~F}$ & $\begin{array}{c}\text { Only attic } \\
\text { pocket }\end{array}$ & $\begin{array}{l}\text { Aditus ad } \\
\text { antrum }\end{array}$ & Primary & $\begin{array}{l}\text { Cholesteatoma in epitympanum } \\
\text { extending to aditus ad antrum } \\
\text { Malleus head, incus long process } \\
\text { erosion }\end{array}$ & TO & $\begin{array}{l}\text { Tragal conposite } \\
\text { graft }\end{array}$ \\
\hline 4 & 51 & M & $\begin{array}{l}\text { Combined } \\
\text { perfora- } \\
\text { tion }\end{array}$ & Mesotympanum & Primary & $\begin{array}{l}\text { Cholesteatoma in epitympanum } \\
\text { \& mesotympanum (stapes tendon, } \\
\text { malleus handle) } \\
\text { Malleus head, incus body partial } \\
\text { erosion }\end{array}$ & TO & Tragal cartilage \\
\hline 5 & 25 & $\mathrm{~F}$ & $\begin{array}{c}\text { Only attic } \\
\text { pocket }\end{array}$ & Limited to attic & Primary & $\begin{array}{l}\text { Cholesteatoma in epitympanum } \\
\text { Incus partially eroded }\end{array}$ & TO & $\begin{array}{l}\text { Tragal composite } \\
\text { graft }\end{array}$ \\
\hline 6 & 37 & M & $\begin{array}{l}\text { Combined } \\
\text { retraction }\end{array}$ & Limited to attic & Primary & $\begin{array}{l}\text { Cholesteatoma in epitympanum } \\
\text { Ossicular chain intact }\end{array}$ & $\mathrm{Tl}$ & $\begin{array}{l}\text { Tragal composite } \\
\text { graft }\end{array}$ \\
\hline
\end{tabular}

TO: tympanoplasty type 0, TM: tympanic membrane

Table 2. Postoperative results of endoscopic attic cholesteatoma removal

\begin{tabular}{|c|c|c|c|c|c|c|c|}
\hline No. & F/U periods $(\mathrm{m})$ & Preop ABG* & $\begin{array}{l}\text { Postop ABG* } \\
\left.\text { (3 months }{ }^{\dagger}\right)\end{array}$ & $\begin{array}{l}\text { Postop ABG } \\
\text { (6 months) }\end{array}$ & $\begin{array}{l}\text { Postop ABG } \\
\text { (12 months) }\end{array}$ & Recurrence $\neq$ & Complications \\
\hline 1 & 26 & 21.7 & 0 & 0 & 0 & $(-)$ & $(-)$ \\
\hline 2 & 15 & 17.5 & 14 & 18.3 & 11.7 & $(-)$ & $(-)$ \\
\hline 3 & 16 & 30 & 20 & 20.8 & 12.5 & $(-)$ & $(-)$ \\
\hline 4 & 14 & 13.3 & 10 & 15 & 10 & $(-)$ & $(-)$ \\
\hline 5 & 6 & 7.5 & 5 & 16.7 & & $(-)$ & $(-)$ \\
\hline 6 & 5 & 14.2 & & & & $(-)$ & $(-)$ \\
\hline Average & 13.66 & 17.36 & 9.8 & 14.16 & 8.55 & & \\
\hline
\end{tabular}

*in pure tone audiogram, tfollow up ABG 3 months after, ffollow up computed tomography image of temporal bone. ABG: airbone gap 
명도 수술 후 6개월째 기도골도 청력차가 $16.7 \mathrm{~dB}$ 로 호전되었 다. 모든 환자에서 추적관찰 기간 중 고막 천공, 이로 인한 이 루나 어지럼증, 이명이나 감각신경성 난청, 안면신경 마비 등 합병증은 발생하지 않았다.

\section{고 찰}

후천성 진주종(primary acquired cholesteatoma)은 이관의 기능부전으로 인한 중이 내 음압의 형성으로 고막 내 함입이 진행되어 내함낭(retraction pocket)이 주로 고막의 이완부에 서 발생하게 되며 내부 상피세포의 이동이 저하되고 케라틴 (keratin)이 축적이 되면서 고막 내의 공간으로 함입이 진행 하게 되어 발병한 진주종의 형태를 일컫는다. ${ }^{11)} \operatorname{Tos}^{12}$ 는 후천 성 중이 진주종을 상고실 진주종, 고실동진주종, 긴장부 함몰 진주종으로 분류하였으며, 이 중 상고실 진주종은 고막 이완 부의 함몰이나 천공으로 정의된다. 상고실 진주종은 상고실함 요(Prussack's space)에서 상고실, 유돌동구(aditus ad antrum) 를 통하여 유양동으로 진행되며 완치를 위해 수술적인 제거 가 필요하다.

이러한 진주종의 제거에 보편화된 수술법으로는 초기 상고 실 진주종의 경우 상고실 개방술과 상고실 재건술(attic reconstruction)이 가장 널리 사용되며 상고실 진주종이 유돌동구 로 진행한 경우에는 유양동삭개술을 시행하게 된다. 수술을 통해 진주종 병변을 완전히 제거하는 것이 중요하며 그와 더 불어 상이관와를 통한 상고실 환기통로를 확보하는 것이 재발 방지에 필수적이다. ${ }^{13)}$

최근 내시경의 발달에 힘입어 의학에 최소 침습적 수술의 개념이 도입되어 여러 분야에 적용되고 있고 관심이 증가하 고 있다. 이비인후과에서는 부비동 수술 시 내시경이 활발히 이용되어 왔으며, 아직까지 이과 영역에서는 현미경을 통한 수 술이 일반적이다. 이과 영역에서는 초기에 진단적인 목적으로 내시경이 주로 활용되었으나 Nomura, ${ }^{14)} \mathrm{Mer}$ 등 ${ }^{15)}$ 에 의해 고 막을 통해 내시경을 사용하여 중이강 내를 탐색하는 시도가 처음으로 도입되었다. 그 후 Poe와 Bottrill ${ }^{16}$ 에 의해 외림프 누공의 진단을 위한 이내시경의 효용성이 보고된 바가 있다. 하지만 최근 몇 년 사이에 점차 내시경을 활용한 중이 수술에 대한 관심이 전 세계적으로 증가하고 있는 추세 ${ }^{17)}$ 이고 실제 임상에서 내시경을 단독으로 이용하여 중이 수술을 시행하 고 좋은 결과를 보고하는 연구 논문들이 발표되고 있다. ${ }^{8,18,19)}$

특히 현미경은 직선 시야를 가지기 때문에 중이강 내의 다 양한 사각 지역에 위치한 병변에 대한 시야 확보가 어려운데 내시경을 활용하면 현미경보다 더 넓은 시야를 확보할 수 있 으며 다양한 각도 $(0,30,45,70$ 도)의 내시경을 교환해가면서
사각 지역의 시야를 확보할 수 있다는 장점이 있기 때문에 상 고실 진주종 수술 시 내시경은 현미경의 단점을 대체할 수 있 는 좋은 접근 기법으로 활용되고 있다. 즉, 현미경을 통해 특 히 경외이도 접근법으로는 시야 확보가 용이하지 않은 중이강 의 주요 구조물인 이소골 및 정원창, 안면신경, 그리고 후고 실의 안면신경와(facial recess), 고실동(tympanic sinus), 상고 실 ${ }^{1820)}$ 에 위치한 병변은 완전히 제거가 어려워 술 후 재발하 기 쉬운 경향이 있고, 이 때 진주종 제거에 다양한 각도 및 넓 은 시야를 확보할 수 있는 내시경을 이용한다면 잔존 진주종 제거 및 진주종의 재발률을 낮출 수 있었다는 연구 결과들이 발표되었다. ${ }^{19,21)}$

Marchioni 등 ${ }^{22)}$ Tarabichi ${ }^{20)}$ 는 중이 진주종의 일차 수술로 경외이도 접근법을 선택하였으며 상고실 진주종 병변의 완전 한 제거와 함께 이소골의 보존이 내시경적 접근에 에 있어서 더 용이함을 보고한 바 있고, Migirov 등ํㅡㄴ 잔존 진주종 혹은 재발성 진주종에 대한 이차 수술법으로 내시경적 접근을 단독 으로 성공하여 재발 및 잔존 진주종을 제거한 결과를 보고 하며 내시경의 효용성에 대하여 강조하였다. Marchioni 등 22,23) 은 중이 진주종이 접근이 어려운 위치에 있는 경우(고실동, 상 고실) 내시경을 유용하게 사용할 수 있다고 보고하였다. 또한 소아 진주종의 경우에도 내시경적 접근법 단독 사용은 병변 의 완전한 제거뿐만 아니라 최소 침습적이라는 측면에서 중 이에 국한된 소아 진주종의 치료에 용이한 수술법임을 연구 하여 발표한 바 있다. ${ }^{733}$ 국내에서는 Jang 등 ${ }^{8}$ 이 유양동삭개 술 중 기존의 현미경적 접근에 내시경적 접근을 병행하였을 경우 고실동 내 잔존 혹은 재발성 진주종 발생 확률을 낮춘다 는 측면에서의 내시경의 효용성에 대하여 소개하였고 경외이 도 내시경 접근법을 통하여 고실성형술을 하였을 때 덜 침습 적이면서 좋은 결과를 보인다는 연구 결과도 발표된 바 있다.

하지만 내시경을 이용한 수술은 단점도 존재하는데 가장 큰 단점은 한 손으로 내시경을 들고 수술을 진행하기 때문에 모든 수술 절차를 다른 한 손으로 진행해야 한다는 점이다. 이는 출혈을 적절하게 수술 시야에서 제거하여 깨끗한 시야 를 확보하는 데 제한점으로 작용하게 된다. 이를 극복하기 위 해 기구 끝에 흡인이 가능한 구멍이 달려 있어 한 손으로 수 술을 할 때에도 깨끗한 시야를 확보할 수 있도록 고안된 도 구들을 사용하는 것이 도움이 된다. 그 외 단점으로 내시경 의 끝에 위치한 렌즈에서 발산되는 열이 내이 및 안면신경에 손상을 줄 수 있다는 점이 있으며 따라서 꼭 필요한 경우가 아니면 내시경을 골륜(bony annulus) 바깥부에 위치시키고 수술을 진행하는 것이 권장된다. 또한 내시경은 이차원적인 평면 시야를 가지기 때문에 수술 시 정확한 깊이감을 가지기 위해서는 많은 연습이 필요하며 내시경을 중이강 내에 위치 
시키고 수술을 진행하는 과정에서 예기치 못한 환자의 움직 임에 외이도벽의 피부나 또는 중이강 내의 주요 구조물들이 손상을 당할 수 있는 위험이 존재하기 때문에 이에 대해 항 상 유의하고 수술을 진행하는 것이 좋다.

본 연구에서 수술 시 진주종에 의한 이소골 침범이 관찰되 지 않아 이소골 연쇄를 보존하면서 진주종의 제거가 가능했 던 3예에서는 기도골도 청력차 $10 \mathrm{~dB}$ 내외의 좋은 청력결과 를 얻을 수 있었다. 또한, 3예에서는 이소골 미란이 관찰되어 침골 및 추골 두부를 제거하고 이차 청력개선술을 계획하였 는데 3예 모두에서 수술 후 추적관찰 시 기도골도 청력차가 $15 \mathrm{~dB}$ 내외로 예상 외로 좋은 청력결과를 얻을 수 있었다. 이 렇게 예상치 못한 좋은 청력결과를 얻은 3예의 수술 후 고막 내시경 소견과 측두골 전산화단층촬영을 분석해 보니 2예에 서 약간의 고막 함몰이 발생하면서 자연적으로 고막이 등골 에 닿았을 것으로 의심이 되며 1 예에서는 상고실 부위의 결 손을 재건하기 위해 삽입한 연골판이 약간 아래로 이동하면 서 등골과의 연결이 생겼을 것으로 추정이 된다. 약간의 고막 함몰이 있는 환자들은 모두 상고실 결손 재건부위로의 함몰 은 관찰되지 않았으나 이관의 기능이 좋지 않을 것으로 추정 되므로 고막 함몰로 인한 진주종의 재발 여부를 지속적으로 관찰하는 것이 필요할 것이다. 일반적으로 내시경을 이용한 진 주종 수술 시 이소골을 제거한 경우에는 본 연구에서처럼 이 차 청력개선술을 계획할 수도 있지만 수술 시 바로 등골과 추 골 사이에 이소골 연쇄를 재건해주는 이소골 재건술을 시행할 수도 있으며 각 수술 상황에 맞는 개별적 접근이 필요하다.

국내 최초로 시도된 본 연구에서는 피부절개 없이 경외이도 적 접근을 통해 내시경을 이용하여 상고실 진주종의 제거수 술이 모든 예에서 성공적으로 가능하였다. 또한, 모든 환자 는 수술 후 다음날 퇴원이 가능하였으며 이는 내시경 접근법 의 또 다른 장점 중 하나라 생각된다. 비록 추적관찰 기간이 짧지만 모든 예에서 잔존 병변이나 재발이 관찰되지 않았고 수술과 관련된 합병증이 발생하지 않았으며 청력 개선도 측 면에서도 우수한 결과를 나타냈다. 즉 유양동 내로 진행하지 않은 비교적 초기의 상고실과 그 주위에 국한된 상고실 진주 종에서는 경외이도 접근을 통한 내시경 수술이 진주종 제거 에 유용하고 효과적인 수술법임을 확인할 수 있었다. 향후 더 많은 환자들을 대상으로 장기간 추적관찰하는 전향적인 연구가 필요할 것이라 생각된다.

\section{REFERENCES}

1) Cho YS, Choi SH, Park KH, Park HJ, Kim JW, Moon IJ, et al. Prevalence of otolaryngologic diseases in South Korea: data from the Korea national health and nutrition examination survey 2008. Clin Exp Otorhinolaryngol 2010;3(4):183-93.

2) Jackler RK. The surgical anatomy of cholesteatoma. Otolaryngol
Clin North Am 1989;22(5):883-96.

3) Strunk CL. Cholesteatoma. In: Bailey BJ, Johnson JT, Newlands SD, editors. Head and neck surgery - otolaryngology. 4th ed. Philadelphia: J.B. Lippincott;1993. p.1635-45.

4) Choi N, Noh Y, Park W, Lee JJ, Yook S, Choi JE, et al. Comparison of endoscopic tympanoplasty to microscopic tympanoplasty. Clin Exp Otorhinolaryngol 2016;10(1):44-9.

5) Tarabichi M. Endoscopic management of cholesteatoma: long-term results. Otolaryngol Head Neck Surg 2000;122(6):874-81.

6) Migirov L, Shapira Y, Horowitz Z, Wolf M. Exclusive endoscopic ear surgery for acquired cholesteatoma: preliminary results. Otol Neurotol 2011;32(3):433-6.

7) Yang CJ, Kim SH, Chung JW. Usefulness of endoscopic removal of congenital cholesteatoma in children. Korean J OtorhinolaryngolHead Neck Surg 2016;59(3):194-201.

8) Jang CH, Kim YH, Jung JK, Kim YH. Endoscopic approach to tympanic sinus during tympanomastoidectomy for cholesteatoma. Korean J Otolaryngol-Head Neck Surg 2001;44(1):32-6.

9) Migirov L, Yakirevitch A, Wolf M. The utility of minimally invasive transcanal endoscopic approach for removal of residual/recurrent cholesteatoma: preliminary results. Eur Arch Otorhinolaryngol 2015; 272(11):3241-6.

10) Marchioni D, Villari D, Mattioli F, Alicandri-Ciufelli M, Piccinini A, Presutti L. Endoscopic management of attic cholesteatoma: a single-institution experience. Otolaryngol Clin North Am 2013;46(2): 201-9.

11) Portman M. The invagination theory for the pathogenesis of cholesteatoma. In: Sade J, editor. Cholesteatoma and mastoid surgery. Amsterdam: Kugler;1982. p.265-6.

12) Tos M. Pathogenesis of sinus and tensa retraction cholesteatoma. In: Sanna, editor. Cholesteatoma and mastoid surgery. Proceedings of the 5th International conference; 1996 Sep 1-6; Alghero, Italy. Rome; CIC Edizioni Internazionali;1997. p.3-8.

13) Park KH. Management of early cholesteatoma. J Clin Otolaryngol Head Neck Surg 2002;13(1):13-9.

14) Nomura Y. Effective photography in otolaryngology-head and neck surgery: endoscopic photography of the middle ear. Otolaryngol Head Neck Surg 1982;90(4):395-8.

15) Mer SB, Derbyshire AJ, Brushenko A, Pontarelli DA. Fiberoptic endotoscopes for examining the middle ear. Arch Otolaryngol 1967; 85(4):387-93.

16) Poe DS, Bottrill ID. Comparison of endoscopic and surgical explorations for perilymphatic fistulas. Am J Otol 1994;15(6):735-8.

17) Kozin ED, Gulati S, Kaplan AB, Lehmann AE, Remenschneider AK, Landegger LD, et al. Systematic review of outcomes following observational and operative endoscopic middle ear surgery. Laryngoscope 2015;125(5):1205-14.

18) Sohn SJ, Park CM, Choe SH, Choi YS, Kwon SW. Endoscopic tympanoplasty. Korean J Otolaryngol-Head Neck Surg 2000;43(6): 598-603.

19) Thomassin JM, Korchia D, Doris JM. Endoscopic-guided otosurgery in the prevention of residual cholesteatomas. Laryngoscope 1993; 103(8):939-43.

20) Tarabichi M. Transcanal endoscopic management of cholesteatoma. Otol Neurotol 2010;31(4):580-8.

21) Brown JS. A ten year statistical follow-up of 1142 consecutive cases of cholesteatoma: the closed vs. the open technique. Laryngoscope 1982;92(4):390-6.

22) Marchioni D, Mattioli F, Alicandri-Ciufelli M, Presutti L. Transcanal endoscopic approach to the sinus tympani: a clinical report. Otol Neurotol 2009;30(6):758-65.

23) Marchioni D, Soloperto D, Rubini A, Villari D, Genovese E, Artioli F, et al. Endoscopic exclusive transcanal approach to the tympanic cavity cholesteatoma in pediatric patients: our experience. Int J Pediatr Otorhinolaryngol 2015;79(3):316-22. 